\title{
Yield and Some Macro-Morphological Characters of Pleurotus pulmonarius (Fries) Quel. Fruit Bodies Cultivated on HCl-Optimized Oil Palm Bunch Substrate
}

\author{
Okwulehie IC ${ }^{1}$, Nwoko MC ${ }^{*}$, Achufusi JN², Onyeizu UR ${ }^{3}$ and Ezera VN1 \\ ${ }^{1}$ Department of Plant Science and Biotechnology, Michael Okpara University of Agriculture, Umudike, Nigeria \\ ${ }^{2}$ Department of Environmental Management and Toxicology, Michael Okpara University of Agriculture, Umudike, Nigeria \\ ${ }^{3}$ Department of Biology, Nwafor-orizu College of Education, Nsugbe, Anambra State, Nigeria
}

\begin{abstract}
This study was conducted to study the yield and some macro-morphological characters of Pleurotus pulmonarius fruit bodies cultivated on Hydrochloric acid $(\mathrm{HCl})$ optimized oil palm bunch $(\mathrm{OPB})$ substrate. Concentrated $\mathrm{HCl}$ was diluted in tap water at $0.1 \%, 0.2 \%, 0.3 \%, 0.4 \%$ and were used to induce changes on the initial $\mathrm{pH}(9.5)$ of OPB to $8.9,8.2,7.9,6.2$ and control (9.1) respectively; after soaking for $48 \mathrm{hrs}$. One way Analysis of variance (ANOVA) and Correlation test were adopted for data analysis. Mean separation was also done by Duncan Multiple Range Test (DMRT) at probability level of $5 \%$. Results showed that $0.1 \%, 0.2 \%, 0.3 \%$ and $0.4 \% \mathrm{HCl}$ treated OPB substrates produced $P$. pulmonarius primordia after $9,9,10,11$ and control (12 days) respectively. Results further revealed that $0.4 \% \mathrm{HCl}$ treated OPB substrate induced the highest $(900 \mathrm{~g} / \mathrm{kg})$ fruit body yield and Biological Efficiency $(90 \%)$ while control $(493$ $\mathrm{g} / \mathrm{kg}$ and B.E $49.3 \%$ ) respectively, produced the lowest quantity of fruit bodies. Some macro-morphological characters of harvested fruit bodies revealed that mean cap size $(\mathrm{C} . \mathrm{Scm})$ and Weight $(\mathrm{wt} . \mathrm{g} / \mathrm{kg})$ of fruit bodies were highest $(3.83$ $\mathrm{cm}$ and $3.5 \mathrm{~g} / \mathrm{kg}$ ) in $0.4 \% \mathrm{HCl}$ treated OPB respectively. Mean Stipe Length $(\mathrm{S} . \mathrm{Lcm})$ was highest $(2.77 \mathrm{~cm})$ in $0.3 \%$ OPB substrate and was significant at $p \leq 0.05$. S.L and C.S of fruit bodies as well as C.S and Wt. were significantly correlated while there was no correlation between S.L and Wt. of fruit bodies. $\mathrm{HCl}$ was found as a suitable acid buffer for the optimization of the $\mathrm{pH}$ of the highly alkaline OPB for cultivation of $P$. pulmonarius fruit bodies. Oil palm bunch should therefore be adopted in the commercial production of the Oyster mushroom if certified safe for human consumption.
\end{abstract}

Keywords: Pleurotus pulmonarius; Substrate; $\mathrm{pH} ; \mathrm{HCl}$

\section{Introduction}

Mushrooms are the reproductive structures of fleshy macro fungi which grow wild in the tropical and sub-tropical rainforest. They are capable of degrading lignin and hence are found naturally growing on different woody and non-woody agricultural residue regarded as substrates [1]. These substrate materials are usually by products from industries, households, agriculture etc, and are usually considered as wastes $[2,3]$. These wastes are actually resources in the wrong place at a particular time [4].

$\mathrm{pH}$ is an important factor for good production of oyster mushrooms. Most mushrooms grow and perform well at $\mathrm{pH}$ near to neutral or slightly acidic at 6.1 and 7.5 respectively [5]. In order to enhance fruit body production, Oyster mushroom growers prefer to use lime $\left(\mathrm{CaCO}_{3}\right)$ as an alkaline buffer to optimize $\mathrm{pH}$ of some acidic substrates [6]. On the other hand, many growers of oyster mushrooms have experienced difficulties in using oil palm bunch as substrate. Achufusi et al. [7] attempted using oil palm bunch as a substrate for the cultivation of P. ostreatus, but recorded no mycelium colonization as well as fruit body yield in the substrate and its supplementations. The substrate was contaminated by Coprinus cinereus (a competitor mushroom that contaminates mushroom beds). The $\mathrm{pH}$ of the substrate was later found to be high at 10.3 and was suggested as the reason for the growth of the competitor-Coprinus sp. and no yield of $P$. ostreatus.

In their separate investigations, Tabi et al. [8] and Lau et al. [9] also reported that $P$. ostreatus was unable to grow on palm empty fruit bunch (EFB) alone and this could be due to high alkaline content of the biomass which does not support mushroom growth. This investigation therefore aims to determine the most efficient means of exploiting Oil Palm Bunch as a substrate for Oyster mushroom production.

\section{Materials and Methods}

\section{Source of culture}

Pure mycelia culture (Spawn) of $P$. pulmonarius was obtained from the science laboratory of Plant Science and Biotechnology, Michael Okpara University of Agriculture Umudike.

\section{Location of study}

The study was conducted in the mushroom house of the department of Plant Science and Biotechnology, Michael Okpara University of Agriculture Umudike, Abia State Nigeria.

\section{Spawn preparation/multiplication}

Spawn of $P$. pulmonarius was prepared using sorghum grains. Sorghum grains were washed in 3 changes of water and soaked overnight. The grains were boiled in tap water for 10-15 minute using gas cooker as a local heat source. Grains was also completely drained of water before mixing with $2 \%(\mathrm{w} / \mathrm{w}) \mathrm{CaCO}_{3}$ and $4 \% \mathrm{CaSO}_{4}$ to optimize $\mathrm{pH}$ and prevent them from clumping respectively as recommended

*Corresponding author: Nwoko MC, Department of Plant Science and Biotechnology, Michael Okpara University of Agriculture, Umudike, Nigeria, Tel: +2348068628368; E-mail: magnuswhitemush@gmail.com

Received November 30, 2017; Accepted December 17, 2017; Published January 02, 2018

Citation: Okwulehie IC, Nwoko MC, Achufusi JN, Onyeizu UR, Ezera VN (2018) Yield and Some Macro-Morphological Characters of Pleurotus pulmonarius (Fries) Quel. Fruit Bodies Cultivated on $\mathrm{HCl}$-Optimized Oil Palm Bunch Substrate. Environ Anal Toxicol 7: 538. doi: 10.4172/2161-0525.1000538

Copyright: @ 2018 Okwulehie IC, et al. This is an open-access article distributed under the terms of the Creative Commons Attribution License, which permits unrestricted use, distribution, and reproduction in any medium, provided the original author and source are credited. 
Citation: Okwulehie IC, Nwoko MC, Achufusi JN, Onyeizu UR, Ezera VN (2018) Yield and Some Macro-Morphological Characters of Pleurotus pulmonarius (Fries) Quel. Fruit Bodies Cultivated on $\mathrm{HCl}-$ Optimized Oil Palm Bunch Substrate. J Environ Anal Toxicol 8: 538. doi: 10.4172/2161-0525.1000538

Page 2 of 4

by Muhammad et al. $[4,10]$. Grains were subsequently packed $2 / 3$ in heat resistant transparent bottles, tightly sealed with Aluminum foil held tight with rubber band before sterilizing in an autoclave at $121^{\circ} \mathrm{C}$ for 30 minutes. After sterilization, bottles were allowed to cool before they were aseptically inoculated with actively growing mycelia of $P$. pulmonarius by grain to grain transfer and incubated in the dark (at 27 $\pm 2^{\circ} \mathrm{C}$ ) until grains were fully colonized by $P$. pulmonarius mycelium $[11,12]$ (Figure 1).

\section{Deterimination of $\mathrm{pH}$ of substrate}

The $\mathrm{pH}$ of solution containing $5 \%$ of sample substrates in $50 \mathrm{ml}$ of distilled water was determined using Jenway 3070 portable automatic temperature compensation digital $\mathrm{pH}$ meter, calibrated with buffer 7-4 and 10 . The $\mathrm{pH}$ value was read on the digital scale.

\section{Substrate preparation}

$1 \mathrm{~kg}$ of Dry OPB substrate was soaked separately in $0.1 \%, 0.2 \%$ and $0.3 \%$ and $0.4 \% \mathrm{HCl}$ solutions made in 1.5 lit. tap water for $48 \mathrm{hrs}$. Another $1 \mathrm{~kg}$ of OPB substrate was also soaked in same amount of tap water and this served as control, according to Colavolpe et al. The $\mathrm{pH}$ of each $\mathrm{HCl}+\mathrm{OPB}$ substrate was determined after $48 \mathrm{hrs}$ of soaking. All the $\mathrm{HCl}+\mathrm{OPB}$ substrate levels were packed in an improvised metallic drum (IMD) and pasteurized for $2 \mathrm{hrs}$ using industrial gas cooker as a local heat source and allowed to cool over night. Various $\mathrm{HCl}+\mathrm{OPB}$ substrates were made into 5 replications and packed in 2.5 liter transparent plastic buckets perforated randomly from bottom to the top.

\section{Substrate inoculation}

$30 \mathrm{~g}$ of grain based spawn of $P$. pulmonarius was spread across each $200 \mathrm{~g}$ of OPB substrate packed in perforated transparent plastic buckets during inoculation [3]. All inoculated substrates were placed on wooden racks in the culture room and covered during spawn run. Humidity of the cropping room was optimized by constantly flooding with tap water. Substrates were regularly checked to ensure optimum moisture content prior to primordial initiation.

\section{Measurement of morphological characters}

Mushrooms growing on substrate of various percentage solutions of $\mathrm{HCl}$ were harvested at maturity. Stipe length and cap size were measured in centimeter using meter rule [3]. Fresh weight of individual fruit bodies was also determined using digital weighing balance.

\section{Yield and biological efficiency}

Harvested fresh fruit bodies from each 5 replicate levels of $\mathrm{HCl}$ treated OPB were weighed using digital weighing balance while Biological efficiency (BE\%) was determined using the method of Chang and Miles.

\section{Statistical analysis}

Data obtained during the experiment were statistically analyzed using Analysis of Variance (ANOVA), mean separation and tests of significance were carried out by Duncan Multiple Range Test (DMRT) at $\mathrm{p} \leq 0.05$ respectively [12].

\section{Results and Discussion}

Table 1 shows the effect of different concentrations of $\mathrm{HCl}$ acid solution on the $\mathrm{pH}$ of $\mathrm{OPB}$ and fruiting duration of $P$. pulmonarius. Result shows that the initial $\mathrm{pH}$ of OPB was found to be 9.5. Different percentage concentrations of $\mathrm{HCl}$ solution altered the $\mathrm{pH}$ of OPB in the following order: $0.1 \%(8.9), 0.2 \%(8.2), 0.3 \%(7.9)$ and $0.4 \%(6.2)$, while control was found at $\mathrm{pH}$ of 9.1 after soaking for $48 \mathrm{hrs}$. This shows that concentrated Hydrochloric acid simply acted as an acid buffer capable of optimizing the $\mathrm{pH}$ of an alkaline OPB substrate to support the growth of mushroom.

The fruiting duration recorded in this work shows that oil palm bunch has the ability of inducing earlier fruiting of $P$. ostreatus and does not conform with the work of Shah et al. which recorded longer fruiting time for $P$. ostreatus on saw dust, wheat straws and other agro wastes combinations. Khan et al. observed relatively shorter fruiting duration when oyster mushroom on different lignocellulosic substrates. They recorded that pin head formation started 7-8 days and matured between 10-12 days of substrates inoculation. This could be that the substrates used contained more nutrients that supported early primordial formation.

During spawn run, all the $\mathrm{HCl}+\mathrm{OPB}$ substrates including the control were colonized by mycelium (Sudirman et al.). Although, Coprinus cinereus, a contaminant mushroom was seen growing on control and other $\mathrm{HCl}+\mathrm{OPB}$ substrates after 6 days, except $0.4 \% \mathrm{HCl}+\mathrm{OPB}$. C. cinereus is a major contaminant in OPB when used in mushroom cultivation, even though pasteurization time is increased. The result also proves that $C$. cinereus grows better in a high alkaline medium as $0.4 \%$ $\mathrm{HCl}$ solution was able to reduce the high alkalinity ( $\mathrm{pH}$ 6.2) of the OPB as well as $C$. cinereus contamination of the substrate.

Duration of primordia initiation shows that $0.1 \%+\mathrm{OPB}$ took 8 days, $0.2 \%+\mathrm{OPB}$ ( 9 days), $0.3 \%+\mathrm{OPB}$ ( 10 days) and $0.4 \%$ OPB ( 11 days) to produce mushroom primordia while control took the longest duration of 12 days. This result conforms to assertion of Khan et al. which maintained that most mushrooms grow better in $\mathrm{pH}$ approximately near to neutral i.e., 7.0, but differ with those of Quimio; Quimio and Sardsud which noted that fruit bodies of $P$. ostreatus grown on various substrates emerged within 3-4 weeks after substrate inoculation. According to them, various factors such as $\mathrm{pH}$, temperature, nature of substrate and method of pasteurization can determine the fruiting time of oyster mushrooms.

Table 2 shows the effect of various $\mathrm{HCl}$ solution concentrations on the yield and B.E (\%) of P. pulmonarius fruit bodies cultivated on OPB substrate. From the result, $0.4 \% \mathrm{HCl}+\mathrm{OPB}$ gave the highest $(900 \mathrm{~g})$ fruit body yield and B.E (90.00\%), followed by $0.3 \%+\mathrm{OPB}(820 \mathrm{~g}), 0.2 \%+\mathrm{OPB}$ $(774 \mathrm{~g})$ and $0.1 \%+(569 \mathrm{~g})$ while control gave the lowest $(493 \mathrm{~g})$ with B.E of $49.30 \%$. This result shows that as the concentration of Hydrochloric acid increased increased from $0.1-0.4 \%$, yield and biological efficiency of $P$. pulmonarius increased from $569.00 \mathrm{~g}$ (56.9\%)-900.00 g (90.00\%) while control $493.00 \mathrm{~g}$ (49.3\%) respectively. This trend was due to Coprinus cinereus which contaminated the substrate, from control to $0.3 \% \mathrm{Hcl}$ OPB (Achufusi). Tabi et al. and Lau et al. [9] had similar experience and reported that $P$. ostreatus was unable to grow on palm empty fruit bunch (EFB) alone and this could be due to high alkaline content of the biomass which does not support mushroom growth. Report of Khan

\begin{tabular}{|c|c|c|}
\hline HCl+OPB (\%) & pH of OPB & Fruiting duration (days) \\
\hline OPB before HCl treatment & 9.5 & - \\
\hline $0.1+$ OPB & 8.9 & 9 \\
\hline $0.2+$ OPB & 8.2 & 9 \\
\hline $0.3+$ OPB & 7.9 & 10 \\
\hline $0.4+O P B$ & 6.2 & 11 \\
\hline Control & 9.1 & 12 \\
\hline
\end{tabular}

OPB=Oil Palm Bunch, $\mathrm{HCl}=\mathrm{Hydrochloric}$ acid

Table 1: Effect of Percentage $\mathrm{HCl}$ Concentrations on the $\mathrm{pH}$ of OPB and Fruiting Duration of $P$. pulmonarius. 
Citation: Okwulehie IC, Nwoko MC, Achufusi JN, Onyeizu UR, Ezera VN (2018) Yield and Some Macro-Morphological Characters of Pleurotus pulmonarius (Fries) Quel. Fruit Bodies Cultivated on $\mathrm{HCl}-$ Optimized Oil Palm Bunch Substrate. J Environ Anal Toxicol 8: 538. doi: $10.4172 / 2161-0525.1000538$

Page 3 of 4

\begin{tabular}{|c|c|c|c|c|c|}
\hline $\begin{array}{c}\mathbf{H C l}+O P B \\
\mathbf{( \% )}\end{array}$ & $\begin{array}{c}\mathbf{1}^{\text {st }} \mathbf{f l u s h} \\
\mathbf{g} / \mathbf{k g}\end{array}$ & $\begin{array}{c}\mathbf{2}^{\text {nd }} \mathbf{f l u s h} \\
\mathbf{g} / \mathbf{k g}\end{array}$ & $\begin{array}{c}\text { Total Yield } \\
\mathbf{g} / \mathbf{k g}\end{array}$ & $\begin{array}{c}\text { D/wt } \\
\text { Substrate/g/kg }\end{array}$ & $\mathbf{B E}(\mathbf{\%})$ \\
\hline $0.1+O P B$ & 490 & 79 & 569 & 1000 & 56.90 \\
\hline $0.2+O P B$ & 604 & 170 & 774 & 1000 & 77.40 \\
\hline $0.3+O P B$ & 626 & 203 & 829 & 1000 & 82.90 \\
\hline $0.4+O P B$ & 604 & 296 & 900 & 1000 & 90.00 \\
\hline Control & 268 & 225 & 493 & 1000 & 49.30 \\
\hline
\end{tabular}

OPB=Oil Palm Bunch, $\mathrm{HCl}=\mathrm{Hydrochloric}$ acid. $\mathrm{D} / \mathrm{wt}=$ dry weight

Table 2: Effect of Percentage $\mathrm{HCl}$ Solution Conc. on the Yield (gm) and Biological Efficiency $(\mathrm{BE} \%)$ of $P$. pulmonarius fruit bodies on OPB substrate.

\begin{tabular}{|c|c|c|c|}
\hline $\mathbf{H C L}+$ OPB (\%) & $\mathbf{S . ~} \mathbf{~}(\mathbf{c m})$ & $\mathbf{C .} \mathbf{S}(\mathbf{c m})$ & $\mathbf{W t} \mathbf{( g / k g})$ \\
\hline $0.1 \mathrm{HCl}+\mathrm{OPB}$ & $2.01 \mathrm{c}$ & $3.17 \mathrm{~b}$ & $2.27 \mathrm{~b}$ \\
\hline $0.2 \mathrm{HCl}+\mathrm{OPB}$ & $2.67 \mathrm{ba}$ & $3.48 \mathrm{ba}$ & $2.68 \mathrm{~b}$ \\
\hline $0.3 \mathrm{HCl}+\mathrm{OPB}$ & $2.77 \mathrm{a}$ & $3.72 \mathrm{ba}$ & $2.79 \mathrm{~b}$ \\
\hline $0.4 \mathrm{HCl}+\mathrm{OPB}$ & $2.49 \mathrm{bac}$ & $3.83 \mathrm{a}$ & $3.59 \mathrm{a}$ \\
\hline Control & $2.23 \mathrm{bc}$ & $2.49 \mathrm{c}$ & $1.54 \mathrm{c}$ \\
\hline
\end{tabular}

OPB=Oil Palm Bunch, $\mathrm{HCl}=\mathrm{Hydrochloric}$ acid. Values are means of 3 replicates, means with the same letters are not significantly different at $p>0.05$.

Table 3: Effect of Percentage HCl Solution Treated Substrate on S.L, C.S and Wt. of Fruit Bodies.

\begin{tabular}{|c|c|c|c|}
\hline & SL & CS & WT \\
\hline SL & - & $0.48^{* *}$ & $0.36^{\mathrm{ns}}$ \\
\hline CS & - & - & $0.59^{* *}$ \\
\hline WT & - & - & - \\
\hline
\end{tabular}

Values are means of 5 replicates. "Significant Correlation; "Highly Significant Correlation; ns: No significant correlation. SL: Stipe length; CS: Cap size; WT: Weight.

Table 4: Correlation Effect $\mathrm{HCl}+\mathrm{OPB}$ Substrates on S.L, C.S and WT of $P$. pulmonarius Fruit Bodies.

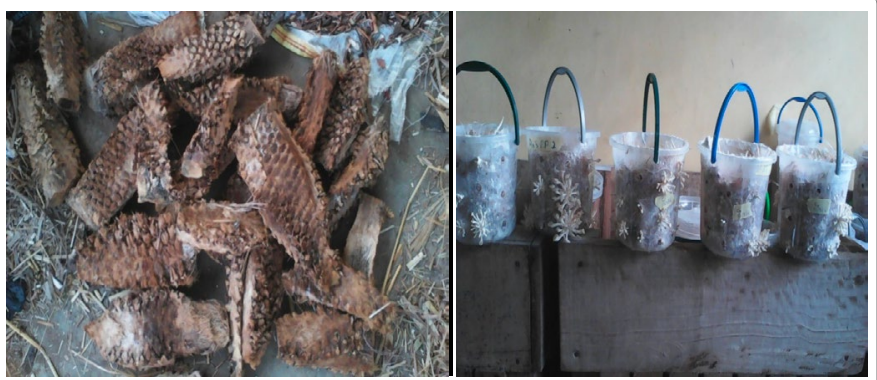

Figure 1: (a) Plate 1: Oil Palm Bunch (OPB) Substrate Plate. (b) Plate 2: $P$. pulmonarius fruit bodies emerging from $\mathrm{OPB}$.

et al. [5] had earlier supported this observation by stating that most mushrooms grow and perform well at $\mathrm{pH}$ near to neutral or slightly acidic at 6.1 and 7.5 respectively.

Table 3 represents the effect of percentage $\mathrm{HCl}$ solution concentrations on the S.L $(\mathrm{cm})$, C.S $(\mathrm{cm})$ and Wt. $(\mathrm{g} / \mathrm{kg})$ of $P$. pulmonarius fruit bodies cultivated on OPB. $0.3 \% \mathrm{HCl}$ treated OPB substrate supported slightly high $(2.77 \mathrm{~cm})$ S.L than others while $0.1 \%$ gave seemingly the lowest $(2.01 \mathrm{~cm})$ S.L. All the percentage $\mathrm{HCl}$ treated substrate including control did not show a significant difference on the stipe length of $P$. pulmonarius fruit bodies at $\mathrm{p}>0.05$ supporting the work of Okwulehie et al. [13]. Cap size (C.S) was smallest $(2.49 \mathrm{~cm})$ in the mushroom produced the control OPB substrate. But the largest $(3.83$ $\mathrm{cm})$ C.S was observed in the $0.4 \% \mathrm{HCl}$ treated OPB substrate. Individual mushroom weight shows an increased gradient from control to $0.4 \%$ $\mathrm{HCl}$ treated $\mathrm{OPB}$ and were not significant at $\mathrm{p}>0.05$. Okwulehie et al. [13] observed that Pennisetum straw significantly increased the stipe

length of $P$. ostreatus, followed by A. gayanus straw, Oryza straw. They also note that Panicum straw causes a reduction of the cap diameter. These findings revealed that substrate has significant effect on the macro-morphological characters of oyster mushrooms. Okoi et al. [14] maintained that different substrates have affect pileus diameter, stipe height and stipe girth. Apart from substrate Hydrochloric acid, Ogbo et al. reported that crude oil has significant effect macro morphological characteristics such as pileus diameter, stipe height, stipe girth, fresh weigh and weight of mushroom fruit bodies. One of the factors responsible for the production of healthy fruit bodies in mushroom industries is the absence of contaminants in the substrates [6]. Steam pasteurization may have ensured more effective pasteurization of the substrates than other techniques studied.

Table 4 represents the result of the relationship between S.L $(\mathrm{cm})$, C.S $(\mathrm{cm})$ and wt. $(\mathrm{g} / \mathrm{kg})$ of $P$. pulmonarius fruit bodies cultivated on $\mathrm{HCl}+\mathrm{OPB}$ substrates. The result shows that there is high level of relationship between S.L and C. S at Rho $=0.48^{\star *}$ but shows no significant relationship between S.L and Wt. (0.36 ns). C.S also shows a high level significant relationship with weight of the fruit bodies $\left(\mathrm{Rho}=0.59^{\star *}\right.$ ). This simply means that S.L of P. pulmonarius fruit bodies with respect to the assay was highly related to C.S while C.S does same to Wt. of the mushroom [15-20].

\section{Conclusion}

In an experiment to determine the effect of $\mathrm{HCl}$ on $\mathrm{OPB}$ substrate for the cultivation of $P$. pulmonarius fruit bodies, it was found that $\mathrm{HCl}$ could be used as a suitable acid buffer to optimize the $\mathrm{pH}$ of alkaline-oil palm bunch $(\mathrm{OPB})$ for the cultivation of $P$. pulmonarius fruit bodies. The $\mathrm{pH}$ of the raw OPB was at alkaline/pH value of 9.5 and in some cases 10.3 or more. Increase in $\mathrm{HCl}$ solution concentration from 0.1 $0.4 \%$, led to an increase in the acidity of OPB substrate from $\mathrm{pH}$ of 8.9 to 6.2 and increase in P. pulmonarius fruit body production while the OPB substrate used as control remained at 9.1. This shows that $\mathrm{HCl}$ is a good acid buffer to adjust the $\mathrm{pH}$ of OPB before it could be used for oyster mushroom.

\section{Recommendations}

Mushroom growers should harness $\mathrm{HCl}+\mathrm{OPB}$ especially at $0.4 \%$ level in the cultivation of $P$. pulmonarius fruit- bodies. Percentage $\mathrm{HCl}$ solution should be increased to 0.5 or $0.6 \%$ to know if they would achieve better yield, Biological Efficiency and other growth parameters investigated in this research Further studies should aim to determine the consumption safety of $P$. pulmonary produced from $\mathrm{HCl}+\mathrm{OPB}$ substrate. Finally, mushroom scientists should identify other cheaper alternative natural or organic acid buffer that would substitute synthetic acid. This could eliminate the irrational safety fear that may arise in the consumption of this mushroom

\section{References}

1. Stamets PS (2003) Growing Gourmet and medicinal mushrooms. Berkeley, USA. Ten Speed Press, p: 554.

2. Okwulehie IC, Nwosu CP, Okoroafor CJ (2007) Pharmaceutical and nutritional prospects of two wild macro-fungi found in Nigeria. Research Journal of Applied Sciences 2: 715-720

3. Okwulehie IC, Okwujiako IA (2008) The use of local Nigerian substrates for the production of Pleurotus ostreatus var. florida (Eger) sporophores. Journal of Dynamic Biochemistry, Process Biotech and Molecular Biology 2: 38-40.

4. Nwoko MC (2015) Yield, heavy metals and nutritional evaluation of pleurotus ostreatus (Jacq) P. Kumm. And Pleurotus pulmonarius (Fries). Quel. Fruit bodies cultivate on three log substrates in Umudike, abia state, Nigeria, p: 19. 
Citation: Okwulehie IC, Nwoko MC, Achufusi JN, Onyeizu UR, Ezera VN (2018) Yield and Some Macro-Morphological Characters of Pleurotus pulmonarius (Fries) Quel. Fruit Bodies Cultivated on HCl-Optimized Oil Palm Bunch Substrate. J Environ Anal Toxicol 8: 538. doi: 10.4172/2161-0525.1000538

Page 4 of 4

5. Khan MW, Ali MA, Khan NA, Khan MA, Rehman A, et al. (2013) Effect of different levels of lime and $\mathrm{pH}$ on mycelial growth and production efficiency of oyster mushroom (Pleurotus spp.). Pak J Bot 45: 297-302.

6. Chang ST, Miles PG (2004) Mushroom cultivation, nutritional value, medicina effect and environmental impact. p: 451.

7. Achufusi JN (2016) Yield, heavy metals, nutritional evaluation, amino acid profile and lignocellulosic evaluation of Pleurotus ostreatus var florida (Eger) fruit bodies cultivated on three supplemented palm substrates in Umudike, Abia State, Michael Okpara University of Agriculture Umudike, Abia State. Nigeria, p: 40.

8. Tabi AN, Zakil FA, Fauzai MF, Ali N, Hassan O (2008) The usage of empty fruit bunch (EFB) and palm pressed fibre (PPF) as substrates for the cultivation of Pleurotus ostreatus. Journal Teknologi 49: 189-196.

9. Lau HL, Wong SK, Bong CFJ, Rabu A (2014) Suitability of Oil Palm Empty Fruit Bunch and Sago Waste for Auricularia polytricha Cultivation. Asian Journal of Plant Sciences 13: 111-119.

10. Ali MA, Siddiq M, Ahmad S, Hanif MA (2007) Protein and fat contents of various Pleurotus species raised on different waste material. Pak J Agric Sci 44: 140-143.

11. Shyam SP, Syed AA, Sureh MT, Mirza MV (2010) The nutritional value of mushroom.

12. Nwoko MC, Onyeizu UR, Chukunda FA, Ukoima HN (2017) Productivity, vitamins and heavy metals analysis of Pleurotus ostreatus (Jacq: fr) kumm. Fruit bodies cultivated on wood logs. International Journal of Information Research and Review 4: 3890-3894.
13. Okwulehie IC, Okwujiako IA, Edeoga HO (2008) Proximate, Macroelement and Vitamin Composition of the Fruit Bodies of Pleurotus ostreatus Var. Florida Eger. Grown on Different Substrates and Substrate Supplementations. Global Sci Books 2: 184-188.

14. Okoi Al, Iboh $\mathrm{Cl}$ (2015) The effects of different substrates on sporophore yield, mineral and nutrient composition of Pleurotus tuberregium fries singer in Calabar, Nigeria. International Journal of Agricultural Science Research 4 126-131.

15. Colavolpe MB, Santiago JM, Edgardo A (2015) Efficiency of treatment for controlling Trichodermaspp.During spawning in cultivation of Lignicolous mushroom. Braz Journal Microbial 45: 1263-1270.

16. Nwoko MC, Okwulehie IC, Achufusi JN (2016) Nutritional composition of Pleurotus ostreatus (Jacq.) kumm P. fruit bodies cultivated on deciduous tree logs in Umudike, Abia State, Nigeria. Intl J Res Tech 5: 102-108.

17. Quimio TH (2004) Why grow mushroom?. Mushroom Growers Handbook, Mushworld, p: 4-7.

18. Quimio TH, Sardsud U (1981) Nutritional requirements of Pleurotus ostreatus (Fr). Philippine Agriculture 64: 79-89.

19. Shah ZA, Ashraf M, Ishtiaq M (2004) Comparative study on cultivation and yield performance of oyster mushroom (Pleurotus ostreatus) on different substrates (wheat straw, leaves, saw dust). Pakistan Journal of Nutrition 3: 158-160.

20. Sudirman LI, Sutrisna A, Listiyowati S, Fadli L, Tarigan BA (2011) The potency of oil palm plantation wastes for mushroom production. Proceedings of the 7 th International Conference on Mushroom Biology and Mushroom Products Arcachon, France, pp: 378-384. 